\title{
Analysis and Visualisation of Research Trends in Hydrogen Fuel: A General Review
}

\author{
Jasgurpreet Singh Chouhan ${ }^{1}$ \\ ${ }^{1}$ Department of Mechanical Engineering Chandigarh University, Gharuan, Mohali, Punjab, 140413
}

Article History: Received: 11 January 2021; Accepted: 27 February 2021; Published online: 5 April 2021

\begin{abstract}
Hydrogen fuel is one of the clean fuels that can replace non-renewable energy sources. Engineering innovations in extraction and distribution are the key challenges to this alternative fuel[1].The bibliometric analysis had been conducted to understand the active authors, organizations, journals, and countries involved in the research domain of "Hydrogen fuel"[2], [3]. All published articles related to "Hydrogen fuel" from "Scopus", were analyzed using the VOS viewer to develop analysis tables and visualization maps. This article had set the objective to consolidate the scientific literature regarding the "Hydrogen fuel"and also to find out the trends related to the same.The most active journals in this research domain were identified as International Journal of Hydrogen Energyand Journal of Power Sources. The most active country was the United States of America. The leading organizations in this research domain were the Russian Academy of Sciences of Russia and Argonne National Laboratory of the United States of America.The most active authorswere Tomasov A.A and Jacobson M.Z.
\end{abstract}

Keywords:Hydrogen fuel,Bibliometric analysis, VOS viewer

\section{Introduction}

Hydrogen fuel is one of the promising solutions to the energy carved world, which is looking for an alternative fuel against the non-renewable resources. Hydrogen is a non-poisonous, colorless, odorless, nontoxic, and tasteless element. Hydrogen is much lighter than air and gasoline vapor. Hydrogen is more prone to leakages due to its low viscosity[4][5]. The major attractive features of hydrogen as an alternative fuel are efficiency, reliability, and environmental benefits. However, the fuel is having the demerits of high manufacturing cost, poor distribution channels'and environmental pollution during the extraction of hydrogen. Hydrogen fuel can be produced from a number of domestic resources like water, hydrocarbons, and organic matter. The main challenge for hydrogen fuels is the extraction of hydrogen fuel cells from their origins. The main two processes of hydrogen extraction are by electrolysis from water and by steam reforming. The major uses of hydrogen fuel are in energy production and as fuels for vehicles. The most promising niches for future research can be on the challenges related to technology for extracting hydrogen.

1.1 Research Objectives

a) To consolidate the literature regarding the Hydrogen fuel

b) To find out the trends related to research in the Hydrogen fuel

The following research questions are framed for conducting bibliometric analysis systematically.

1.2 Research Questions

a) Who are the active researchers working on Hydrogen fuel?

b) Which are the main organizations and countries working on Hydrogen fuel?

c) Which are the main journals related to Hydrogen fuel?

1.3 Significance of this research

Hydrogen fuelis a clean fuel with ecological and economic effects. There are a lot of limitations for the complete replacement of non-renewable resources by alternative fuels, especially, Hydrogen fuel. This article points out the need for future research regarding Hydrogen fuel, its extraction technology, costs, and benefit. This bibliometric analysis will be a useful platform for future researchers by realizing the top researchers, organizations, and countries involved in Hydrogen fuelsystems. This bibliometric article is arranged in four sections. The first section is the introduction, followed by the discussion of the methodology by which the research was conducted. The third section deals with results and discussion. The fourth section deals with the conclusion.

\section{Research Methodology}

Scopus resource was used to prepare this bibliometric analysis regarding "Hydrogen fuel". For the article selection, the Boolean used was TITLE ("Hydrogen fuel") on 03/01/2021. All the tables in this paper were created by using Microsoft Excel and VOS Viewer. Grammarly was used for spelling and grammar checks. Mendeley was used for article review and citation. This paper had been inspired by bibliometric analysis in its presentation style, analysis, and methodology from the works. ${ }^{7-11}$ 


\section{Results and discussion}

1.1 Results

This first round of search produced an outcome of 1187 documents, inninelanguages, out of which 1110 documents were in English. The classification of document categories is shown in Figure 1. For improving the quality of the analysis, we had selected only the peer-reviewed articles and all other documents had not been considered. Thus after using filters "Article"and "English" the second round search produced an outcome of 524 English articles (both open access and others) andhad been used to conduct bibliometric analysis and visualization using VOS Viewer. The English research articles in this domain since 1967 had been shown in Figure 2.

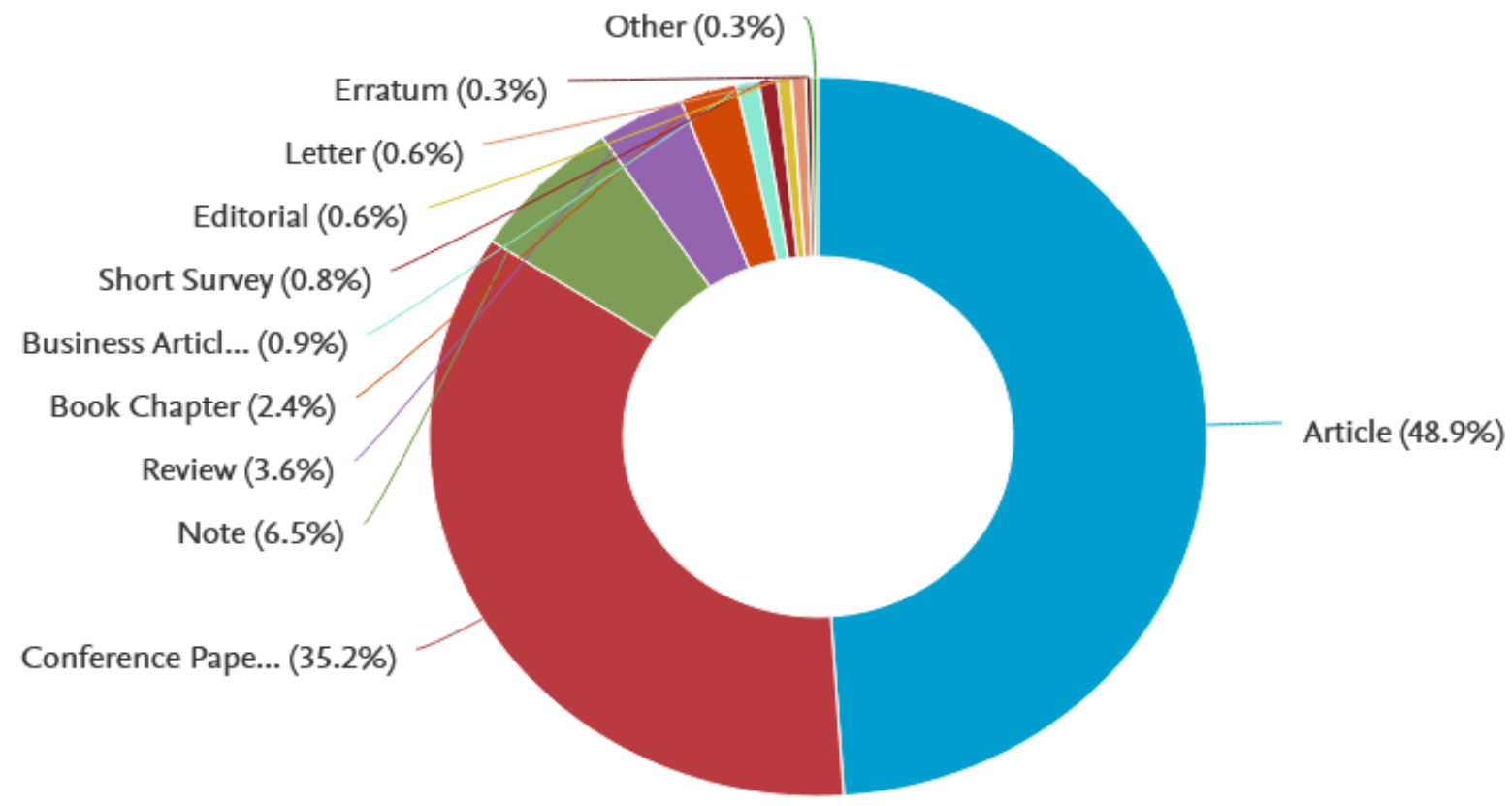

Figure 1: Classification of the documents on "Hydrogen fuel", Source: www.scopus.com

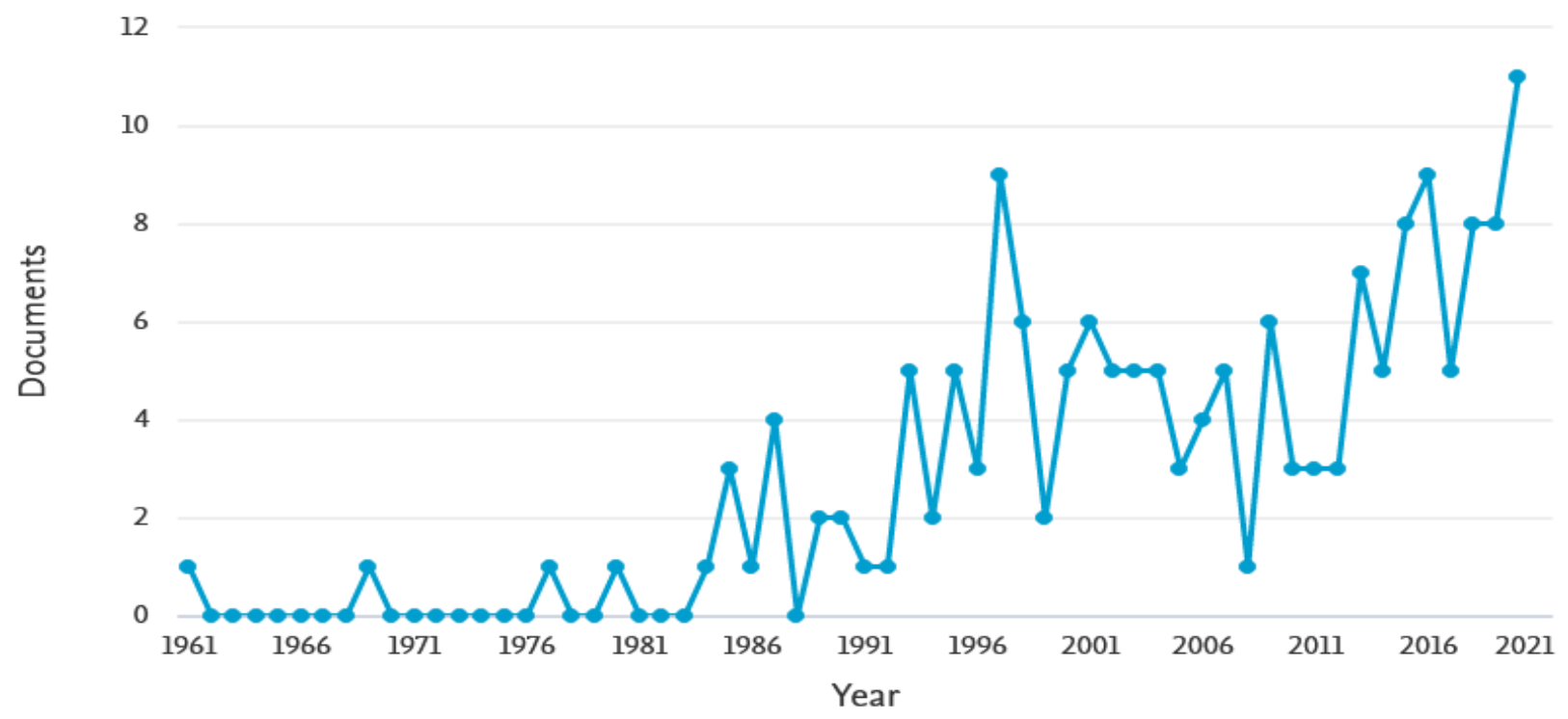

Figure 2: Period wise publication of articles, Source: WWW.scopus.com

Co-authorship analysis of top authors had been shown in figure 3. For a better presentation of the analysis, the parameters used were the minimum number of documents of an author as fourand the minimum number of citations of authors as one. This combination plotted the map of 26 authors, in 15 clusters. The overlay visualization map of co-authorship analysis plotted in Figure 3, points out the major researchers with their strong co-authorship linkages and clusters involved. 


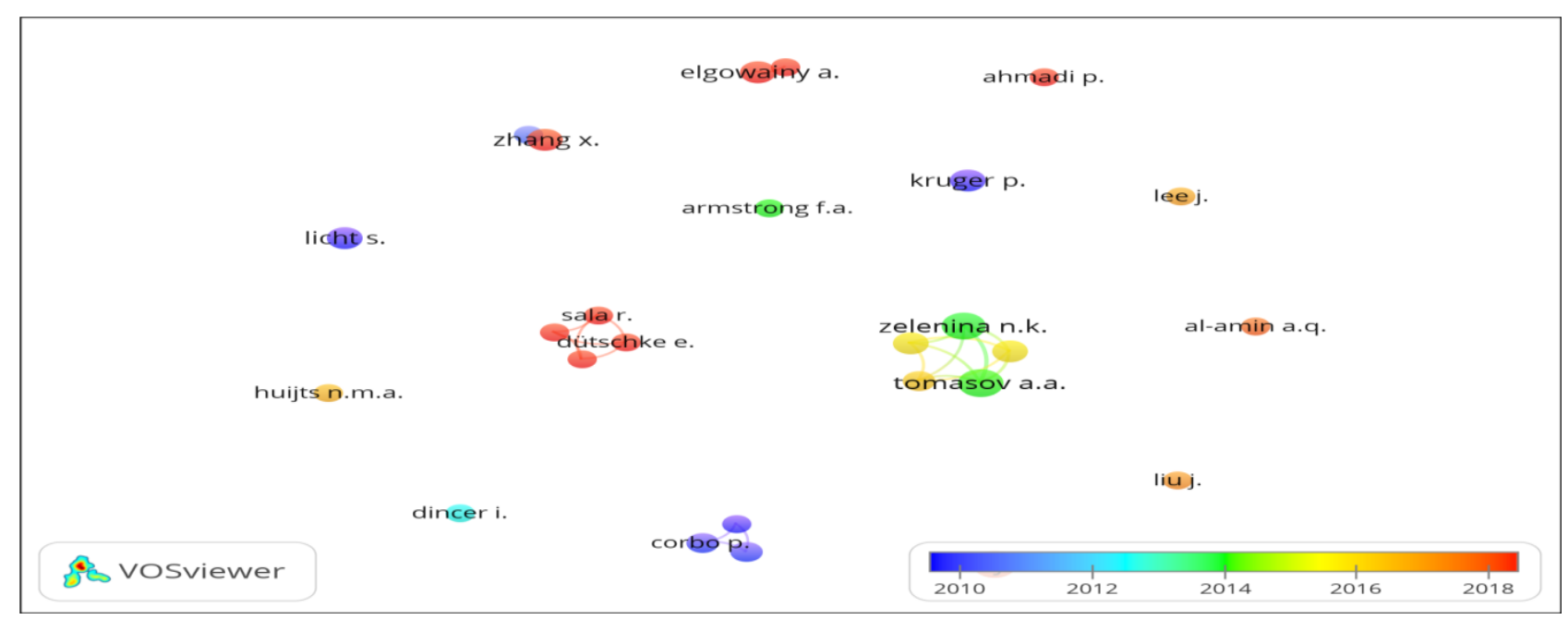

Figure 3: Co-authorship analysis on basis of authors

The citation analysis of top authors had been shown in table 1, along with co-authorship links.For the citation analysis, the parameters used werethe minimum number of documents of an author as one and the minimum citations of an author as one.

Table 1: Highlights of most active authors

\begin{tabular}{|c|r|r|r|r|}
\hline Description & Authors & Document & Citations & Link strength \\
\hline $\begin{array}{c}\text { Authors with the highest } \\
\text { publication and co-authorship links }\end{array}$ & & & & \\
& Tomasov A.A & 10 & 26 & 43 \\
\hline Authors with the highest citation & Jacobson M.Z. & 03 & 809 & 04 \\
\hline
\end{tabular}

In Co-occurrence analysis, we had used all keyword analyses, by keeping the minimum number of occurrences of a keyword as 20 . This combination plotted the map of 27thresholds, in fiveclusters. The overlay visualization of co-occurrence analysis of keywords has been shown in Figure 4.

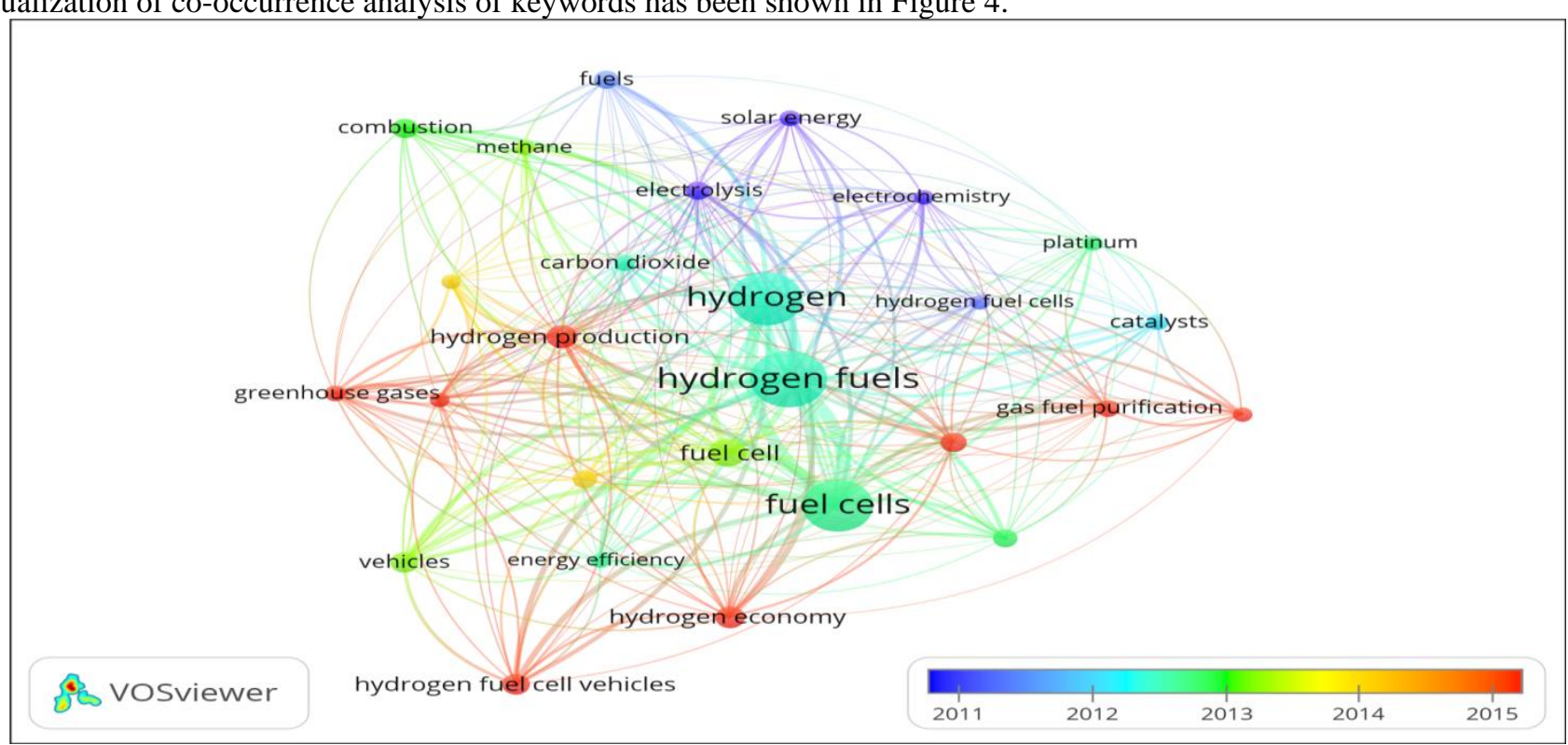

Figure 4: Co-occurrence analysis on basis of all keywords

The most leadingorganizations engaged in research on "Hydrogen fuel" had been found out by the number of publications and citation analysis, the parameters used are the minimum number of documents of an organization as one and the minimum number of citations of organizations as one. This combination plotted the map of 820organizations, in 404clusters. 
The leading research organization engaged in the research regarding "Hydrogen fuel" with the highest number of publications and citationswere the Russian Academy of Sciences of Russia and Argonne National Laboratory of United States of America (Refer to table 2).

Table 2: Highlights of the most active organization

\begin{tabular}{|c|c|c|c|c|}
\hline Organizations & Country & Documents & Citatio & $\begin{array}{c}\text { Average } \\
\text { Citations } \\
\text { document }\end{array}$ \\
\hline per \\
\hline Russian Academy of Sciences & Russia & 19 & 402 & 20.0 \\
\hline Argonne National Laboratory & $\begin{array}{c}\text { United States } \\
\text { of America }\end{array}$ & 12 & 595 & 49.6 \\
\hline
\end{tabular}

Co-authorship analysis of the countries engaged in the research on "Hydrogen fuel" had been shown in Figure 5. For a better presentation of the analysis, the parameters used were the minimum number of documents of an author as seven and the minimum number of citations of authors as one. This combination plotted the map of 21 countries,5clusters. The overlay visualization map of co-authorship analysis plotted in Figure 5, points out the main countries with their strong co-authorship linkages and clusters involved.

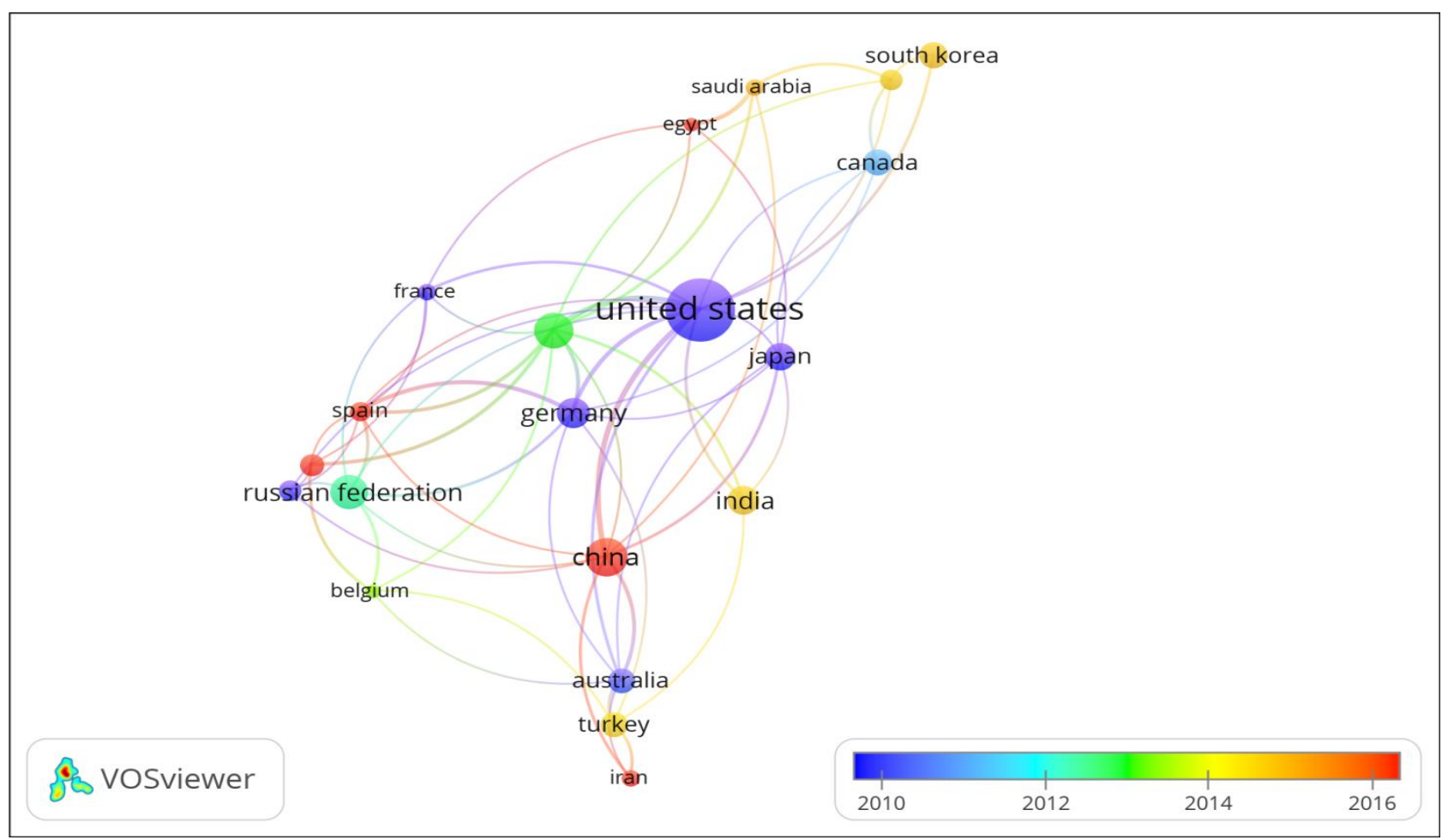

Figure 5: Co-authorship analysis on basis of countries

The citation analysis of top countries had been shown in table 3, along with co-authorship links. For the citation analysis, the parameters used were the minimum number of documents of acountry as one and the minimum citations of the country as one.

Table 3: Highlights of Active Countries

\begin{tabular}{|c|c|r|r|r|r|}
\hline Description & Country & Docume & Citatio & \multicolumn{1}{|c|}{$\begin{array}{c}\text { Average } \\
\text { citations } \\
\text { documents }\end{array}$} & $\begin{array}{c}\text { Link } \\
\text { strength }\end{array}$ \\
\hline $\begin{array}{c}\text { The country with the } \\
\text { highest publication, citation, } \\
\text { and co-authorship links }\end{array}$ & $\begin{array}{l}\text { United } \\
\text { States of } \\
\text { America }\end{array}$ & 128 & 3495 & & \\
\hline
\end{tabular}

The most active country in this research domain wasthe United States of America with the highest number ofpublications, citations, and co-authorship links. 
Link analysis and citation analysis were used to identify the most active journal in this research domain. We have taken the parameters of the minimum number of documents of a journal as one and the minimum number of citations of a journal as one for the link analysis and citation analysis. Highlights of the most active and relevant journals related to the "Hydrogen fuel"are shown in table 4. Table 4shows the journal activity of this research domain through parameters of publication volume, citations, and co-authorship linkages. International Journal of Hydrogen Energywas the most active journal with the highest publications, citations, and co-authorship links, followed by Journal of Power Sources.

Table 4: Analysis of journal activity

\begin{tabular}{|c|c|r|r|r|r|}
\hline Description & Journal details & Documen & Citatio & $\begin{array}{c}\text { Average } \\
\text { citations per } \\
\text { ds }\end{array}$ & $\begin{array}{c}\text { Link } \\
\text { strength }\end{array}$ \\
\hline $\begin{array}{c}\text { Journal with the } \\
\text { highest publications, } \\
\text { citations, and co- } \\
\text { authorship links }\end{array}$ & $\begin{array}{l}\text { Journal of Hydrogen } \\
\text { Energy }\end{array}$ & 143 & 3573 & 24.98 & 44 \\
\cline { 2 - 6 } & $\begin{array}{l}\text { Journal of Power } \\
\text { Sources }\end{array}$ & 27 & 1218 & 45.1 & 25 \\
\hline
\end{tabular}

From the above discussion regarding the bibliometric patterns in the research regarding the Hydrogen fuel,this research had observed a gradual increase in research interest regarding the Hydrogen fuel from the starting of the millennium and the momentum is going on positively. This point out the relevance and potential of this research domain (Refer to Figure 2). The most active author in this research domainis Tomasov A.A and Jacobson M.Z.with the highest publication, citations, and co-authorship links (Refer to table 1).The overlay analysis of top countries researching Hydrogen fuelindicates that the United States of Americawas the leading country in research regarding Hydrogen fuelwith the highest publications, citations, and co-authorship links(Refer to figure 5). The top journals of this research domain were identified as International Journal of Hydrogen Energyand Journal of Power Sources.Fromthese wide sources of information, researchers can focus on leading journals, authors, organizations, and countriesengaged in the research regarding Hydrogen fuel.

\section{Conclusion}

Hydrogen fuelis an interesting research domain and the most active journals related to this alternative energy source are the International Journal of Hydrogen Energyand Journal of Power Sources. The most activecountrywas the United States of America.The leading organizations engaged in the research regarding Hydrogen fuel[6][10]were the Russian Academy of Sciences of Russia and Argonne National Laboratory of the United States of America.The most active authors who had made valuable contributions related to Hydrogen fuelwere Tomasov A.A and Jacobson M.Z.This research domain offers a new avenue for researchers and future research can be on the extraction of hydrogen, technologies, distribution of hydrogen fuel, and cost reduction in extraction.

\section{References}

1. P. Gairola, S. P. Gairola, V. Kumar, K. Singh, and S. K. Dhawan, "Barium ferrite and graphite integrated with polyaniline as effective shield against electromagnetic interference," Synth. Met., vol. 221, pp. 326-331, 2016.

2. C. S. Hearn et al., "Design and demonstration of an extended range hydrogen fuel cell utility vehicle," in 2011 IEEE Vehicle Power and Propulsion Conference, VPPC 2011, 2011.

3. J. Rugolo, B. Huskinson, and M. J. Aziz, "Model of performance of a regenerative hydrogen chlorine fuel cell for grid-scale electrical energy storage," J. Electrochem. Soc., vol. 159, no. 2, pp. B133-B144, 2012.

4. S. Kumar, M. Kumar, and A. Handa, "Combating hot corrosion of boiler tubes - A study," Eng. Fail. Anal., vol. 94, pp. 379-395, Dec. 2018.

5. K. M. Batoo et al., "Structural, morphological and electrical properties of $\mathrm{Cd} 2+\mathrm{doped} \mathrm{MgFe} 2-\mathrm{xO} 4$ ferrite nanoparticles," J. Alloys Compd., vol. 726, pp. 179-186, 2017.

6. S. K. Das and K. K. Gadde, "Experimental performance evaluation of a combustion heat-assisted catalytic flat plate fuel reformer for fuel cell grade hydrogen," Int. J. Hydrogen Energy, vol. 40, no. 46, pp. 15913$15922,2015$.

7. I. V Aleksandrova, E. R. Koresheva, O. N. Krokhin, and I. E. Osipov, "Cryogenic hydrogen fuel for controlled inertial confinement fusion (formation of reactor-scaled cryogenic targets)," Probl. At. Sci. Technol. Ser. Thermonucl. Fusion, vol. 38, no. 4, pp. 51-78, 2015.

8. T. Yoshida and K. Kojima, "Toyota MIRAI fuel cell vehicle and progress toward a future hydrogen society," Electrochem. Soc. Interface, vol. 24, no. 2, pp. 45-49, 2015.

9. M. H. Khooban, N. Vafamand, and J. Boudjadar, "Tracking Control for Hydrogen Fuel Cell Systems in ZeroEmission Ferry Ships," Complexity, vol. 2019, 2019. 
10. A. Chitsazan, M. Monajjemi, H. Aghaei, and M. Sayadian, "Neutral gases adsorption with hydrogen on silicon nanotubes: A fuel cell invistegation," Orient. J. Chem., vol. 33, no. 3, pp. 1366-1374, 2017. 
